\title{
UNIVERSALIZATION OF ELEMENTARY EDUCATION: CHALLENGES, ISSUES AND EFFORTS
}

\author{
Parvaiz Ahmad Dar \\ Department of Education, Central University of Kashmir, Jammu \& Kashmir, India
}

\begin{abstract}
The Indian education system is perhaps the largest system in the world catering the need of millions of students of different socio-economic background. Education is globally acknowledged as the most powerful means of empowerment. Education is utmost important for every child irrespective of its gender. It is disheartening that, even in current modern scenario, some people are still against the education of the girl children. Every child has the right to receive elementary education however, Due to many factors girls are forced to leave school while others never have been provided an opportunity to enroll in schools. Among children not attending schools there are more girls than boys and among illiterate adults, there are more women than women. Many girls continue to dropout that adversely affects the efficiency of the education system and respective progressive expectations. The unfinished task in terms of un-enrolled and out-of-school girl child is the manor challenge. Rigorous and continuous efforts are required to bring and retain girl children under the purview of education system. The community and government schemes in this direction, can jointly play a vital role in bringing and retaining girl children to schools for primary and secondary education. To understand the problems and challenges faced by girls at elementary education level the author conducted a study in education zone Magam. The zone progressed significantly but still it has many areas of concern that are primarily responsible for un-fulfilment of the goals of universal literacy. There are number of problems which become hindrance in the way of education of girls but whatever the reason is if significant efforts were taken this problem can be then tackled easily. So, the authors hope that this study can help us to illuminate some of the complexities around education of the girls at elementary level and bring new insight to policy makers and educational practitioners.
\end{abstract}

Key words: Access, Enrolment, Retention, Elementary Education

\section{INTRODUCTION}

Education is systematic process through which a child acquires knowledge, experience, skills, and sound attitude. It makes a child civilized, refined, cultured, and educated. For a civilized and socialized society education is the only means. Every society gives importance to education because it is the panacea for all evils. It is the key to solve various problems of life. All over the world, education is regarded as a potential investment for the future. An old proverb lies down. "If you are planning for one year, plant rice: if you are planning for five years, plant a tree and if you are planning for the future, educate your children". That is education is always considered as a ladder of development. It dispels darkness and brings light. Education is considered to be the most vital asset in any society because this is an old proven fact that knowledge is the priceless wealth and strongest survival tool that people will never mislay under any circumstances. Furthermore, the knowledge gets shared the further it advances every time it is shared. Nevertheless, elementary education forms the foundation of basic knowledge without which the goals of education and the dreams of a civilized society becomes impossible.

\section{Elementary Education}

Elementary education can be understood as the first stride that a person takes in life, and it is impractical for anyone to run without first learning how to walk. So far as elementary education in India is concerned, it comprises of eight years of schooling for the age group of 6 to 14 years. It combines of two stages of education:

- Primary school stage: From I to V class.

- Upper primary school stage: From VI to VIII class.

Education is a major instrument for change and social development which plays an important role in empowering the girl child. Free and compulsory education to all children up to the age of fourteen years is the Constitutional commitment in India. Kotwal, N., Neelima, \& Rani, S. (2007) studied the 
causes of school dropout among rural girls in Kathua district of Jammu and Kashmir and found that majority (86\%) of the parents were not interested in re-admission of their daughters. They were satisfied with their daughter's performance in the household activities and were now waiting to get them married. Only $14 \%$ of parents were interested in the continuation of their daughter's studies but cannot because of poverty. Denteh, W.O., \& Amedeker, M.A. (2011) also investigated the cause and effects of female school dropouts and found that the Parents irresponsibility, extra cost of schooling, overworking and tiredness, are some of the factors responsible for dropping of the children from school:

The female literacy rate is lower than the male literacy rate. The ground reality is deprivation of girls especially girls from poor families and those belonging to deprived sections of the society. Education is globally acknowledged as the most powerful means of empowerment. Hence, education for girls must be paid special attention. Greater access for girls to education must be ensured in the educational system. Gender sensitivity must be developed. A watch must be kept on enrolment, retention and dropout rate of girls and corrective measures should be taken to check the dropout rates. To understand the problems and challenges faced by girls at elementary education level the author conducted a study in education zone Magam of District Budgam. The zone has significantly progressed but still it has many areas of concern that are primarily responsible for un-fulfilment of the goals of primary literacy and enrolment of girls in schools.

\section{OPERATIONAL DEFINITIONS}

- Access: availability of schooling facility accessible for girls in the locality.

- Enrolment: Children who are enrolled in any educational institution and attend the regular classes for the purpose of education.

- Retention: Means retaining of the student in the school until they complete the elementary education.

\section{OBJECTIVE OF THE STUDY}

- To find out the total number of schools available in the education zone Magam.

- To find out the total number of girls in the age group of 614 years enrolled in schools.

- To find out the total number of girls who have never been enrolled in school.

enrolled in school.

\section{5 (C) Author(s)}

- To find out the total number of girls in the age group of 06-14 years who got dropout from the school.

- To find out the causes responsible for non-enrolment of girls in schools.

\section{V.METHODOLOGY}

The selection of methods for research work depends upon the nature of the problem selected. Mainly methodology consists of tools, techniques, and procedures. The success of investigation depends on the priority of the method and the tools and techniques the researcher uses.

\section{RESEARCH DESIGN}

The present study has been completed through the survey method of research. This method has been the most popular and widely used method of research in social science and education. Survey studies investigate phenomena in their natural setting.

\section{Tools Used}

In the present study, self-constructed information blank was used as a tool for data collection.

\section{Procedure of Data Collection}

The investigator collected the data from the selected education zone through formal and informal interactions with the concerned and through door-to-door survey wherever needed.

\section{RESULTS AND DISCUSSION}

The result and discussions of the present study is based on the field level data collected from female students, girls, Teachers, parents, community and from other sources. The research was guided by an interest of understanding the access, enrolment, and retention of girls at elementary level. Results and discussion of the study are as under:

Table 1: Accessibility of Schools in the Area

\begin{tabular}{|c|c|c|c|c|}
\hline Table 1: Accessibility of Schools in the Area \\
\begin{tabular}{|c|c|c|c|c|} 
School type & Primary & Middle & $\begin{array}{c}\text { Primary/middle/secondary/higher } \\
\text { secondary }\end{array}$ & $\begin{array}{c}\text { Grand } \\
\text { Total }\end{array}$ \\
\hline Government & 27 & 16 & 4 & \multirow{5}{*}{5} \\
\hline Private & 2 & 4 & 2 & \\
\hline Total & $\mathbf{2 9}$ & $\mathbf{2 0}$ & $\mathbf{6}$ & \\
\hline
\end{tabular}
\end{tabular}

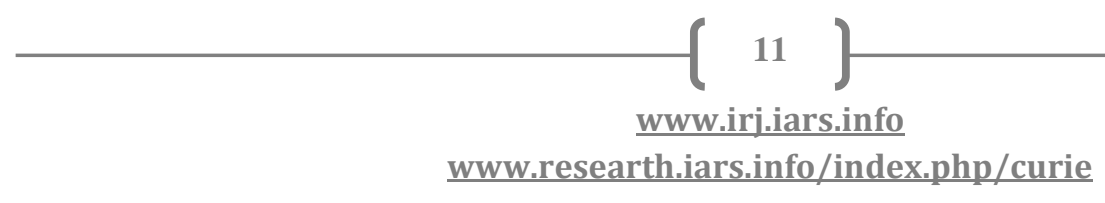




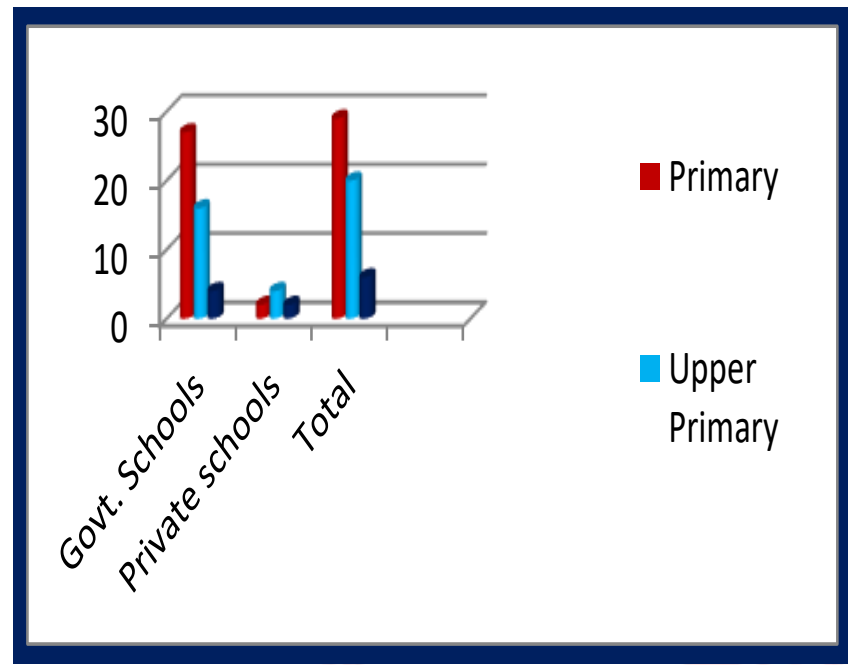

Figure 1: Graph Showing Accessibility of Schools in the Area

The Table-1 and Figure-1 show shows that out of 55 total schools available in the education zone Magam, 29 are primary schools. Among 29 primary schools, 27 are government primary schools and 2 are private. There are 16 government Middle schools and 4 private Middle schools, so the total number of middle schools available in the Zone are 20 and the number of schools that fall in the category of primary/upper primary/secondary/Higher secondary are 6 out of which 4 are government and 2 are private.

The Table- 2 and Figure- 2 show that the total number of girls enrolled in government and private schools from class I to VIII is 1492, out of which 1021 are enrolled in government schools and 471 girls are enrolled in private schools. The graph also indicates that, there is a slight difference in the enrolment of Girls in government and private school. Another interesting finding is that the enrolment of girls is least at VIII standard.

Table 2: Enrolment of Girls

\begin{tabular}{|c|c|c|}
\hline Class & Government school & Private school \\
\hline & Girls & Girls \\
\hline Class I & 192 & 71 \\
\hline Class II & 126 & 60 \\
\hline Class III & 127 & 57 \\
\hline Class IV & 131 & 65 \\
\hline Class V & 117 & 53 \\
\hline Class VI & 127 & 64 \\
\hline Class VII & 114 & 57 \\
\hline Class VIII & 87 & 44 \\
\hline \multirow{3}{*}{ Total } & $\mathbf{1 0 2 1}$ & $\mathbf{4 7 1}$ \\
\cline { 2 - 3 } & \multicolumn{2}{|}{$\mathbf{1 4 9 2}$} \\
\hline
\end{tabular}

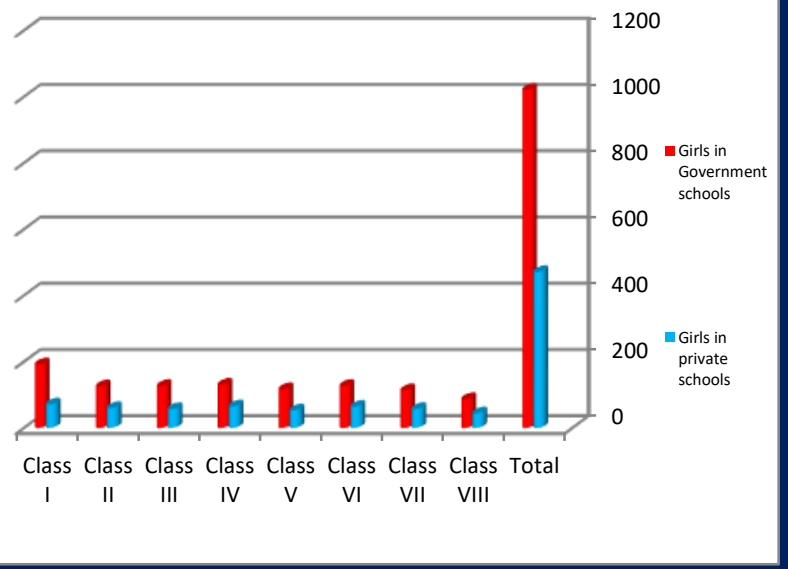

Figure 2: Graph Showing Enrolment of Girls

Table 3: Girls Never Enrolled and Dropouts

\begin{tabular}{|c|c|c|c|}
\hline AGE & NEVER ENROLLED & DROPOUT & TOTAL \\
\hline 06 to 14 Years & 07 & 06 & 13 \\
\hline
\end{tabular}

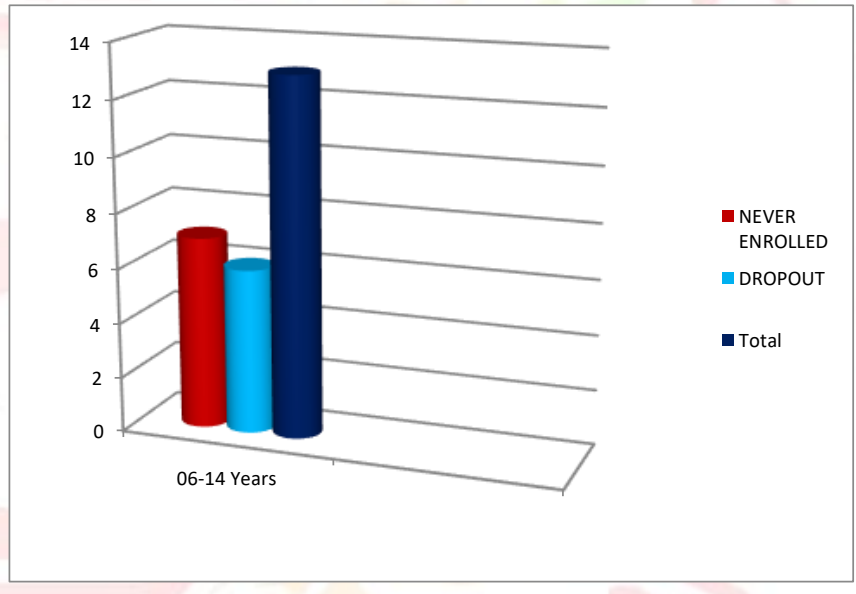

Figure 3: Graph Showing Girls Never Enrolled and Dropouts

The Table- 3 and Figure-3 show that there are 07 girls in education zone Magam who have been never enrolled in any type of schools. It also indicates that, there are 06 girls in the age group of 06-14 years that got dropout from school, which means that these 06 girls are admitted either in government or in private schools but due to one or other reason they left the school without completing the elementary education. So, the total number of girls in the age group of 06 to 14 years that don't receive any type of elementary education at present in education zone Magam is 13. 


\section{Yinternational Research Journa}

p-ISSN 2202-2821 e-ISSN 1839-6518 (Australian ISSN Agency)

\section{CHALLENGES AND ISSUES}

Based on the analysis and interpretation presented, one gets the impression that the Magam zone significantly progressed but still it has certain areas of concern, which become barrier in the way of education of girls at elementary level. Challenges and issues which arise after analyzing and interpreting the data are:

- Across the zone, schools are accessible within the walking distance of each girl. But a few schools still do not have their own school buildings.

- The enrolment ratio observed at the upper primary level is much lower than that at the primary level.

- A few numbers of girls continue to dropout from the schools' incomplete year cycle, which severely affects the efficiency of the education system.

- The dropout rate is more at the primary stage that is in the age group of 06-11 years.

- In education zone Magam, the total number of girls that are still out of school in the age group of 06 to 14 years is 13.

- There are some schools in the area that do not have adequate number of teachers and instructional rooms.

- 13 girls in the age group of 06-14 years are still out of schools due to one reason or other. Some of the causes responsible for this are:

- Unattractive, incomplete schools and Unfavorable school environment.

- Lack of awareness among parents regarding the importance of education of girls.

- Lack of essential basic facilities in schools especially separate toilet for girls.

- Inefficient teaching learning material and outdated teaching learning methods which laid more emphasis on cramming.

○ Poverty of parents or low family economic status.

- Gender disparity between the education of boys and girl.

- Lack of proper inspection and supervision in schools.
Vol. 11 No. 022021

828011022021165 (C) Author(s)

- Lack of essential facilities for education of differently able children as most of the schools doesn't have ramp connectivity available for physically handicapped children.

- Strict physical punishment to students in schools which decreases the motivation level of the student.

- Long illness of children, broken families and Death of parents are also to some extent responsible.

\section{CONCLUSION}

Just as strong foundation is very important for a building, in the same way elementary education is important for the progressive development of the child's personality. Unless the goal of Universalization of elementary education is not achieved, the dream of Universalization of secondary education is not likely to be realized. A few numbers of girls continue to dropout from the education system before completing an education cycle. This adversely affects the efficiency of any education system. The unfinished task in terms of un-enrolled and out-of-school girl children is a big challenge. Rigorous and continuous efforts are required to bring and retain them under the benefits of education systems. Appropriate steps must be carried out to improve the enrolment and retention of girls in schools. Girls should be encouraged to pursue elementary education by providing scholarships and by fulfilling other necessary requirements. Parents and community at large can play a vital role in bringing and retaining un-enrolled girl children to schools.

\section{REFERENCES}

[1]. Bauddha, V. (1997). Sociology of Education. In Wankhande, G.G. NCERT; Survey of Educational Research. 6 (1), 573.

[2]. Denteh, W.O., \& Amedekar, M.A. (2011). Causes and effects of Female school dropouts and the financial impact on Governmental Budget: Case study: Ayeduass Township. Continental Journal of Social Science, 4 (2), 1-7.

[3]. Dorough, C. (2003). A study of dropout characteristics and school level effects on dropout prevention ( $\mathrm{Ph}$. D thesis, University of Louisiana, Louisiana, United States of America) Retrieved from http://etd.lsu.edu/docs/available/etd-0710103021510/ 
[4]. Govindaraju, R., \& Venkatesan S. (2010). A study on School dropouts in Rural Settings. Kamla Raj Journal of Psychology. 1 (1), 47-53.

[5]. http://en.wikipedia.org/wiki/ Millennium_development_goals.

[6]. Human Development in South Asia (2000). Report publishes for the Mahbub-ul-Haq, Human Development Center. Retrieved from http://mhhdc.org/wpcontent/themes/ report.

[7]. Jagathkar, A. (2016) Draft National Education Policy 2016: Will it help in achieving education outcomes?", IARS' International Research Journal. Vic. Australia, 6(2). doi: 10.51611/iars.irj.v6i2.2016.60.

[8]. Jagathkar, A. and Jain, D. (2020) Digitized Education: A New Social Divide between Rural and Urban India, IARS' International Research Journal. Vic. Australia, 10(1). doi: 10.51611/iars.irj.v10i1.2020.115.

[9]. Jain, D. (2019) “Don't Kill Innovation: Concept Towards A New Academic World", IARS'
International Research Journal. Vic. Australia, 9(1). doi: 10.51611/iars.irj.v9i1.2019.98.

[10]. Khan, S., \& Pandey G. (2012). Causal factors of School dropouts: A study of Aligarh District, U.P. International Journal of Research in Social Sciences. 2 (1), 236-241.

[11]. Kotwal, N., Neelima, \& Rani, S. (2007). Causes of School dropouts among rural girls in Kathua district. Kamla Raj Journal of Human and Ecology. 22 (1), 57-59

[12]. Maikhuri, Rama. (2005). Status of Elementary Education in rural areas of Chamoli district of Uttaranchal. Indian Educational Abstracts. 8 (1), 3536.

[13]. NSSO (1998). Attending an educational institution in India: its level, nature and cost (NSSO. 52nd Round 1996-1997) Report No. 439. Government of India, New Delhi.

[14]. www.kashmirlife.net/school-education-an-officialstory-30425. 


\section{Manuscript Processing Footprints}

\section{A. Journal Volume/Issue Details}

This manuscript it published in Vol. 11 No. 022021 issue of IARS' International Research Journal (I'IRJ).

This is a Peer Reviewed (Refereed) International Journal published by IARS' Press Australia (International Association of Research Scholars) The Volume/Issue is a regular issue of the journal published in August 2021 Available at: https://researth.iars.info/index.php/curie.

\section{B. Copyright, License, and Publishing Rights}

- IARS' Press Australia (International Association of Research Scholars) respects the rights of the authors of research content published with IARS' International Research Journal. The "First Publication Rights" (FPR) to the original work accepted for publication at IARS' International Research Journal is granted to the Publisher of the Journal but copyright for all work published in the journal is retained by the author(s). Works published in the Journal is distributed under a Creative Commons Attribution 4.0 International License (CC B Y 4.0). (This license lets others distribute, remix, adapt, and build upon your work, even commercially, as long as they credit you for the original creation. This is the most accommodating of licenses offered. Recommended for maximum dissemination and use of licensed materials.)

- After publishing the content with IARS' International Research Journal, the author holds complete right on the content for its amendments and reuse in any form. IARS' International Research Journal confirms that author(s) holds the copyright of the content.

- $\quad$ Author(s) grant(s) permission for their work to be indexed in part/full form in commercial and non-commercial indexes. Author(s) grant(s) permission for their work to be harvested in part/full form in commercial and non-commercial archives and distributed through them. Author(s) grant(s) permission for their work to be translated in part/full form in any language and republished and redistributed. Author(s) may enter into separate, additional contractual agreements for the non-exclusive distribution of the published version of the work, with an acknowledgement of its initial publication in this Journal.

- It is the responsibility of the author(s) to secure all necessary copyright and/or permissions for the use of third-party content in their manuscript(s). Author(s) have declared the same at the time of submission of manuscript and 'may also be required' to provide written evidence of this permission anytime in case required for any purposes.

- Publications Ethics and other Terms and Conditions as mentioned on official website of IARS' International Research Journal.

\section{Last Plagiarism Report}

Settings: Similarity of 09 words in a row has been considered plagiarized.

Plagiarized (4\%) $\square$ Unique (96\%)

\begin{tabular}{|l|l|}
\hline Date & Aug 13, 2021. \\
\hline Words & 89 Words Plagiarized / Total Words 2413. \\
\hline Source & 3 Source(s) Identified. \\
\hline Remarks & Low similarity detected, check your supervisor if changes are required. \\
\hline
\end{tabular}

Exemption / Relaxation by Editor: None

\section{Processing Track}

\begin{tabular}{|l|l|}
\hline Date of Submission & 09 June 2021 \\
\hline Date of Final Review & 02 August 2021 \\
\hline Date of Acceptance \& Schedule & 15 August 2021 \\
\hline Date of Publishing & 29 August 2021 \\
\hline
\end{tabular}

